\title{
A magyarországi várandósgondozási rendszer sajátosságai: a magán- és állami ellátások igénybevétele mögött húzódó egyenlőtlenségek
}

\author{
Boros Julianna dr. ${ }^{1,2}$ - Kopcsó Krisztina dr. ${ }^{2}$ - Veroszta Zsuzsanna dr. ${ }^{2}$ \\ ${ }^{1}$ Semmelweis Egyetem, Általános Orvostudományi Kar, Magatartástudományi Intézet, Budapest \\ ${ }^{2}$ Központi Statisztikai Hivatal, Népességtudományi Kutatóintézet, Budapest
}

Bevezetés: Jóllehet Magyarországon a várandósok a társadalombiztosítási rendszer által támogatott komplex várandósgondozási ellátásra jogosultak, mégis sokan vesznek közülük igénybe privát szolgáltatásokat. Ezt a döntést többek között a biztonságérzet fokozása és a várandósgondozást végző szakember szülésig tartó folytonosságának biztosítása motiválja. Nemzetközi szakirodalmi adatok alapján mindemellett feltételezhetô, hogy hazánkban is befolyásolja a választást a társadalmi-gazdasági helyzet.

Célkitüzés: A jelen elemzés célja annak vizsgálata magyarországi várandósok reprezentatív mintáján, hogy az állami/ magán/vegyes finanszírozású várandósellátás igénybevétele mennyiben kapcsolódik bizonyos demográfiai, szocioökonómiai, egészségi és pszichológiai változókhoz.

Módszer: Az elemzés a Kohorsz '18 Magyar Születési Kohorszvizsgálat első, várandós anyák körében zajló szakaszának súlyozott adatain történt $(\mathrm{n}=8287)$. Az adatok forrását a védőnők által szóbeli interjúk során felvett, valamint önkitöltős formában begyújtött kérdőíves adatok szolgáltatták.

Eredmények: Az egyes várandósgondozási formák igénybevétele erôsen összefüggött a várandós korával, iskolai végzettségével, anyagi helyzetével és foglalkozási presztízsével. Közepes erősségű kapcsolatban állt a várandós partnerkapcsolati helyzetével és meglévő gyermekeinek számával, míg gyenge összefüggésben az egészségi állapotával és pszichés tüneteivel. A finanszírozási formához mindemellett erôsen kapcsolódott az, hogy a várandós választott orvossal, szülésznővel tervezte-e szülését.

Megbeszélés: A kapott eredmények rámutatnak, hogy a várandósellátás különböző finanszírozású formáinak igénybevétele jelentôs mértékben együtt jár a várandós szocioökonómiai és demográfiai sajátosságaival, míg egészségi és pszichés állapotával csupán gyenge összefüggésben áll.

Következtetés: A hazai várandósgondozást jellemző kettős finanszírozás háttér-egyenlőtlenségek egész sorát hordozza magában. Jövőbeli elemzésekben vizsgálat tárgyává szükséges tenni, hogy ez mennyiben mutat összefüggést ellátásminőségi és -hozzáférési különbségekkel, valamint ezeken keresztül a várandós és gyermeke egészségével.

Orv Hetil. 2021; 162(35): 1402-1412.

Kulcsszavak: várandósság, várandósgondozás, magán/állami/vegyes ellátás, Kohorsz '18

\section{Characteristics of the Hungarian pregnancy care system: background inequalities in the preferences for private and public care}

Introduction: While pregnant women in Hungary are entitled to complex pregnancy care financed by the social security system, many of them do use private services. This decision is motivated, among other things, by increasing the sense of security and ensuring the presence of the doctor providing pregnancy care at the birth. However, based on the international literature, it can be assumed that this decision is influenced by the socio-economic background as well.

Objective: The aim of the present analysis is to examine the extent to which the use of public/private/mixed funded pregnancy care is related to certain demographic, socioeconomic, health related and psychological variables on a representative sample of pregnant women in Hungary. 
Method: The analysis was performed on the weighted data of the first, pregnant wave of the Cohort ' 18 Growing Up in Hungary $(\mathrm{n}=8287)$. The analysis is based on data from personal interviews and self-administered questionnaires conducted by the health visitors among pregnant women in 2018.

Results: The use of different forms of pregnancy care was strongly related to the age of the pregnant women, their education, financial situation and occupational prestige. It was moderately correlated with the pregnant woman's partnership status and their parity, while it was weakly correlated with her health status and psychological symptoms. The form of financing of the pregnancy care was, however, strongly related to whether the pregnant woman planned to give birth with a chosen doctor or midwife.

Discussion: The results show that the use of different forms of pregnancy care is greatly associated with the socioeconomic and demographic characteristics of the pregnant women, while it is only weakly related to the health status and mental wellbeing.

Conclusion: Double funding in the Hungarian pregnancy care system carries a whole range of background inequalities. Future analyses should examine whether this has an impact on the quality and availability of care and, indirectly, on the health of pregnant women and their children.

Keywords: pregnancy, maternity care, private/public/mixed funded care, Cohort '18

Boros J, Kopcsó K, Veroszta Zs. [Characteristics of the Hungarian pregnancy care system: background inequalities in the preferences for private and public care]. Orv Hetil. 2021; 162(35): 1402-1412.

(Beérkezett: 2021. február 15.; elfogadva: 2021. március 9.)

\section{Rövidítések}

FEOR = Foglalkozások Egységes Osztályozási Rendszere; ISCO $=($ International Standard Classification of Occupations $)$ Foglalkozások Egységes Nemzetközi Osztályozása; KSH = Központi Statisztikai Hivatal; NKI = Népességtudományi Kutatóintézet; SD = standard deviáció; $\mathrm{SEI}=($ socioeconomic index) társadalmi-gazdasági index; SIOPS $=($ standard international occupational prestige scale) standard nemzetközi foglalkozásipresztízs-skála; tb = társadalombiztosítás; WHO = (World Health Organization) Egészségügyi Világszervezet

A magyar várandósgondozási rendszer számos szereplő együttmúködésén alapuló komplex egészségügyi szolgáltatás [1]. A várandósság során végzett gondozási tevékenység fó célja az anya és a magzat egészségének védelme, ennek érdekében a gondozási folyamat résztvevői folyamatosan nyomon követik a várandós nő egészségét, és tanácsokkal segítik elő a magzat fejlődését; igyekeznek felismerni a veszélyeztetettséget és megelőzni az esetleges szövődményeket, felkészítik a várandóst a szülésre és az anyaságra. A gondozási folyamat során a szülészorvos mellett kiemelkedő szerep jut a védőnőnek, a háziorvosnak és a szülésznőnek. Az alapellátásban a védőnő koordinálja a várandós gondozását, a háziorvos feladata pedig a szükséges vizsgálatokra, laborba történő beutalás, a várandós egészségének nyomon követése. A szakellátásban alacsony rizikójú terhesség esetén a várandós választhat szülészorvos helyett szülésznőt, illetve természetesen igénybe veheti a szülész-nőgyógyász szakorvos szolgáltatásait.

Hazánkban a várandósgondozási rendszer igénybevételére a magzati élet védelme érdekében valamennyi várandós jogosult. A társadalombiztosítási (tb-) rendszer által támogatott szolgáltatások mellett azonban a váran- dósok jelentős hányada privát szolgáltatásokat is igénybe vesz a gyermekvárás során. Felvetődhet a kérdés, hogy emögött milyen okok, motívumok húzódhatnak meg.

Az Egyesült Királyságban és Írországban végzett korábbi kutatások rámutatnak, hogy a várandósgondozás formájának és a szülés helyszínének megválasztásakor a nők által mérlegelt fontos szempontok a következők: biztonság; a várandósgondozást biztosító szakember személyének folytonossága; az egyénre szabott gondozás; a korszerú újszülöttellátáshoz és szükség esetén az orvosi ellátáshoz való hozzáférés; a többféle fájdalomcsillapítási mód közötti választás lehetósége; valamint az ellátásukat illető bizonyos kérdésekben való saját döntés joga [2-4]. Magyarországi nők körében végzett kvalitatív felmérés szerint ezzel összhangban a szülő nőknél az orvosválasztás és a hálapénzadás fő motivációja a biztonságérzet, a megfelelő ellátás iránti igény, valamint az, hogy a fogadott orvos jelen legyen a szülésnél [5].

A várandósgondozás kettős rendszere, a választott orvos intézménye révén, kevésbé formálisan ugyan - hiszen a várandósgondozással ellentétben a szülések jelentős része állami kórházakban zajlik -, de egészen a szülésig determinálja az ellátás minőségét, a beavatkozások gyakoriságát, magában hordozva a háttér-egyenlőtlenségek egész sorát [6].

Az egészségügyi ellátórendszer társadalmi meghatározottságainak enyhítésére átfogó WHO-irányelv vonatkozik [7]. A 2016. évi WHO-ajánlás a szülő nók igényeinek felmérésére alapozva egyebek mellett a szülésznő vagy bába várandósgondozásban játszott szerepét hangsúlyozza, a kora terhességi időszaktól egészen a gyermekágyas szakaszig [8]. A szülésznők folyamatos támogatására alapozott ellátórendszerhez kötődő várakozások épp a szocioökonómiai hátrányokból származó negatív egészségi következmények enyhítésére vonatkoznak 
(részletező összegzését lásd [9]). A magán- és állami ellátás kombinációja azonban még az általános bábaellátás esetén is társadalmi különbségeket hordoz.

Az egészségügyi ellátáshoz való hozzáférés társadalmi egyenlőtlenségei a várandósellátás kapcsán kiemelt figyelmet érdemelnek [10]. Az ezen időszakban tapasztalt ellátásminőségi, hozzáférési hátrányok az anya egészsége mellett a gyermek későbbi fejlődésére is kihatnak, sajátos módon örökítve ezáltal a szociodemográfiai státuszt [11, 12]. Ez a kapcsolat a szülés kimenete, a gyermek állapota és fejlődése és az anya szocioökonomiai státusza között még a teljes körű és egységes állami egészségügyi ellátást biztosító tb-rendszerekben is kimutatható [13]. A magán- és állami ellátórendszerek kiegészítő egymás mellett élése - amely számos egészségügyi szisztéma sajátja többnyire a magánellátáshoz kapcsolható fokozottabb társadalmi egyenlőtlenségeket mutat [14-16].

A hazai egészségügyben a várandósgondozási-szülészeti ellátásban különösen dominál e kettős finanszírozási forma jelenléte. A szintén állami/magán/vegyes finanszírozású várandósgondozási szisztémán alapuló ír ellátórendszer friss vizsgálatában Moran és mtsai [17] a kora terhességtől a gyermekágy időszakáig kérdezték az anyákat. Jóllehet fơ kutatási kérdésük az ellátás minőségének és a beavatkozások gyakoriságának alakulása volt az eltérő finanszírozási módok esetén (lásd erről a hazai eredményeket: [18]), a kutatás az egyes ellátási formákat igénybe vevők háttérjellemzőit is vizsgálta. Eszerint a szociodemográfiai meghatározottságok egyértelműen kihatnak a terhesgondozási forma melletti döntésekre. A magánellátás igénybevétele esetén - mely az ír adatok alapján jócskán elmarad a magyarországi gyakoriságtól az idősebb, magasabb státuszú, írországi születésű anyák dominálnak. A rizikófaktorok és az ellátási típus közti összefüggésre is e háttérjellemzők hatnak ki a leginkább.

A tb-vel, illetve az ún. „orvosi segéllyel” (Medicaid) rendelkező várandósok körében mindemellett, egyváltozós statisztikai eljárásokkal vizsgálva, a praenatalis depresszió előfordulása is magasabb, mint a magánbiztosítással rendelkezők körében [19]. Többváltozós statisztikai módszereket alkalmazva ugyanakkor a biztosítási státusz már nem jósolta meg a depressziószintet, vagyis a magasabb depressziószint hátterében vélhetően a biztosítási státusszal szorosan összefüggő társadalmi, demográfiai, egészségügyi, kapcsolati és egyéb pszichológiai változók (így például magasabb szorongásszint) álltak.

Mindebből azt a következtetést vonhatjuk le, hogy a hazai várandósellátás különböző finanszírozású formáinak igénybevételéhez az anyák szocioökonómiai és demográfiai sajátosságai mellett a pszichés és fizikai egészségük is kapcsolódhat, mindezen tényezők pedig a gyermeket váró nők és magzataik komplex egyenlőtlenségi rendszerét hozzák létre. Elemzésünk célja ennek az összetett egyenlőtlenségi rendszernek a feltárása magyarországi várandósok reprezentatív mintáján.

\section{Módszer}

\section{Minta és eljárás}

A jelen tanulmány a Központi Statisztikai Hivatal (KSH) Népességtudományi Kutatóintézete (NKI) által folytatott Kohorsz '18 Magyar Születési Kohorszvizsgálat első, várandósszakaszának adatfelvételén alapul. A Kohorsz '18 kutatás súlyozott, várandós-adatbázisa ( $\mathrm{n}$ = 8287) a 2018-ban várandós anyák populációjára nézve reprezentatív (az iskolai végzettséget, a paritást, a hivatalos családi állapotot, az életkort, illetve a lakhely fejlettségi mutatóját tekintve), és azon, gyermeket váró nők közel 10\%-át foglalja magában, akik szülésének várható időpontja a várandósgondozási könyvben rögzített adatok alapján 2018. április 1. és 2019. április 30. közötti időszakra esett (lásd bővebben [20, 21]).

A mintavétel a védőnői körzeteken alapuló és a területek társadalmi státuszát is figyelembe vevő, véletlen kezdőpontú szisztematikus mintavétellel történt. A mintába kerülő védőnői körzetekben az adott időszakra gyermeket váró nőknek a kutatásra való felkérése teljes körú volt.

A várandósok felkérését és lekérdezését az NKI által erre felkészített védőnők végezték, a várandósok tájékoztatását és írásos beleegyezését követően. Az adatfelvétel ajánlott ideje a várandósság 28-31. hete közé esett. A várandósok lekérdezése az esetek 3\%-ában ennél korábban (de legkorábban a 20 . héten), 11\%-ában pedig ennél később történt. A megkérdezett nők átlagosan várandósságuk 30,12. hetében jártak $(\mathrm{SD}=2,16)$.

A válaszadók életkora az adatfelvétel időpontjában 13 és 49 év között változott $(M=29,61 ; S D=6,05)$. A várandósok 98,6\%-a (8172 fó) egy magzatot, 1,4\%-a (114 fó) két magzatot várt, 1 fó pedig hármas ikreket. A kutatás módszertanáról és a mintáról részletes információkat tartalmaz a témában megjelent két jelentés [21, 22].

\section{Változók és méröeszközök}

A jelen elemzés a várandós-adatfelvétel két forrására, a védőnők által szóban lekérdezett fókérdőív súlyozott adataira és a gyermeket váró nők által kitöltött önkitöltős kérdőív ehhez kapcsolt adataira támaszkodik.

Azt, hogy a várandós milyen finanszírozású várandósellátást vesz igénybe, a fơkérdőív azon kérdése alapján határoztuk meg, hogy a válaszadó jelenlegi várandóssága kapcsán saját bevallása szerint „tb-támogatott rendelésen”, „magánrendelésen” vagy „mindkét fajta rendelésen” járt nőgyógyásznál vagy szülésznőnél várandósgondozáson.

A mögöttes társadalmi egyenlőtlenségek megragadásához a rétegződés hagyományos vertikális indikátorait, a társadalmi-gazdasági háttér index (SEI) alkotóelemeit [23] vontuk be az elemzésbe, úgymint iskolai végzettség, jövedelem és foglalkozásipresztízs-komponensek. Az előbbi kettő esetében a társadalmi tőke eloszlása 
mentén értelmezett egyenlőtlenségek hagyományos, Bourdieu-féle felosztását alkalmazzuk, melyben az iskolai végzettség a kulturális, a jövedelmi helyzet a gazdasági tőke egyszerüsített mérését képviseli. Az 'iskolai végzettség' változó a befejezett képzési szinteken alapul. A jövedelmi változó bázisa az önkitöltős kérdőívmodulban az anya által - a háztartás elmúlt havi nettó jövedelmeként - zárt vagy nyitott kérdésben megadott érték. Az alkalmazott változó az ekvivalens - egy háztartástagra jutó - havi háztartás-jövedelmi kvintiliseket tartalmazza, ennek létrehozására a tisztított havi háztartási jövedelem folytonos változó értékeiből és a háztartásnagyság változójából került sor. Azok esetén, akik csak kategoriális háztartás-jövedelmet adtak meg, a jövedelmi értéket a kategóriaátlaggal helyettesítettük. Ez esetben tehát nem az egyén (anya), hanem a család jövedelmi helyzetével dolgozunk. A foglalkozási presztízs változója azonban már a várandós anyához kapcsolódik. A változó kialakítása során először az anya által szabadszavasan megadott (utolsó) foglalkozásnév FEOR-08 [24] rendszerű besorolását végeztük el. Ezt követően transzformáltuk a magyar foglalkozási nómenklatúrát a nemzetközi ISCO-08 [25] négy számjegyes rendszer kódjaivá, a KSH által kidolgozott fordítókulcs [26] használatával. Ez biztosította a Treiman által kidolgozott nemzetközi foglalkozásipresztízs-skála [27], a SIOPS (standard international occupational prestige scale) [28] rendelkezésre álló nemzetközi pontszámainak hozzárendelhetőségét [29]. Az ez alapján létrejött folytonos változóból foglalkozásipresztízs-harmadokat alakítottunk ki annak érdekében, hogy a változó a hierarchizáltság mellett külön itemként magában foglalhassa a foglalkozással még nem rendelkező válaszadó anyák csoportját is, tehát azokét, akik még soha nem dolgoztak.

Az egészségi állapotra vonatkozóan a szubjektív egészség mérésére alkalmazott ötfokú Likert-skálát használtuk, a „nagyon jó”-tól a „nagyon rossz”-ig terjedő válaszlehetőségekkel, a várandósságot megelőző l évre, illetve a kérdezés idejére, tehát a várandósság 7. hónapjára vonatkoztatva. A szubjektív egészség az egyén önérté- kelésén, nem pedig orvosi diagnózison alapul, de a szakirodalomban általánosan elfogadott, hogy a valós egészségi állapot jó indikátora, ezért az egészségi állapotra vonatkozó felmérésekben rendszeresen alkalmazott eszköz. Emellett felmértük azt is, hogy van-e a várandósoknak valamilyen krónikus betegségük, amely legalább 6 hónapja tart, vagy előreláthatólag legalább 6 hónapig fog tartani.

A depresszióra utaló tünetek felmérése a négyfokú Likert-skálát alkalmazó 'Center for Epidemiologic Studies - Depression' kérdőív [30] nyolctételes változatával [31] történt (Cronbach- $\alpha=0,760)$, Szeifert fordítása alapján [32], a szorongásos tüneteké pedig a négyfokú Likertskálát alkalmazó 'Generalized Anxiety Disorder-2' skála [33] magyar fordítása (http://www.phqscreeners.com) révén (Cronbach- $\alpha=0,702)$. Végül a várandóssággal összefüggő szorongás felmérésére a négyfokú Likertskálát alkalmazó, 9 tételes Várandóssággal Összefüggő Gondolatok Kérdőívet [34, 35] alkalmaztuk (Cronbach- $\alpha$ $=0,829)$. A depresszióskála, valamint a Várandóssággal Összefüggő Gondolatok Kérdőív adatait legalább 80\%os kitöltöttség esetén a személy által megválaszolt tételek átlagpontszámával helyettesítettük. A mérőeszközökről további információ a vonatkozó kutatási jelentésben olvasható [21].

\section{Adatelemzés}

Az adatok elemzése SPSS Statistics 22 programmal (IBM Corporation, Armonk, NY, Amerikai Egyesült Államok) történt. Az állam által biztosított várandósgondozási ellátás, a magánjellegű várandósellátás és a két forma vegyes igénybevételének a demográfiai, társadalmi-gazdasági, egészségi és egyes pszichológiai változókkal mutatott összefüggéseit khí-négyzet-próbákkal vizsgáltuk. Emellett a különféle ellátást igénybe vevő várandósoknak a depresszív és szorongásos tünetek mentén mutatott különbségeit Kruskal-Wallis-tesztekkel, ezek eredményeit pedig utókövető Mann-Whitney-próbákkal elemeztük.

1. táblázat |A várandósgondozási formák igénybevételének megoszlása választott orvos és/vagy szülésznő megléte szerint

\begin{tabular}{lccc}
\hline $\begin{array}{l}\text { Van vagy lesz Önnek választott } \\
\text { szülészorvosa vagy szülésznője, } \\
\text { aki jelen lesz a szülésnél? }\end{array}$ & A 7 . hónapig igénybe vett várandósgondozás típusa \\
\cline { 2 - 4 } & $\begin{array}{c}\text { Tb-támogatott } \\
\mathrm{n}(\%)\end{array}$ & $\begin{array}{c}\text { Vegyes } \\
\mathrm{n}(\%)\end{array}$ & $\begin{array}{c}\text { Magán } \\
\mathrm{n}(\%)\end{array}$ \\
\hline Mindkettő van vagy lesz & $222(10,5)$ & $804(38,0)$ & $1091(51,5)$ \\
\hline Csak szülészorvos & $529(18,6)$ & $1128(39,8)$ & $1180(41,6)$ \\
\hline Csak szülésznóle Vearson-féle $\chi^{2}$
\end{tabular}

$\mathrm{n}=8112 ; \mathrm{Tb}=$ társadalombiztosítás

${ }^{*} \mathrm{p}<0,001$

a df =6, vagyis a Cramér-féle V 0,04 érték felett jelez gyenge, 0,12 érték felett közepes és 0,2 érték felett erős összefüggést 


\section{Eredmények}

\section{A várandósgondozási formák igénybevétele és összefüggése a szakemberválasztással}

A nőgyógyászati vizsgálatot a várandósok valamivel több mint harmada $(39,8 \%)$ vette igénybe kizárólag a tb által finanszírozott ellátás keretében, a többiek pedig nagyjából egyenlő arányban oszlottak meg a mind magán-, mind az állami vizsgálaton részt vevő́k $(29,6 \%)$, illetve a csak magánellátást igénylők $(30,6 \%)$ közöttt.

Amint az 1. táblázatban látható, a különféle várandósgondozási formák igénybevétele erôs összefüggést mutat azzal, hogy a várandós választott orvossal, szülésznővel tervezi-e szülését, vagy választott szakember nélkül. Míg a 83,7\%-a azon várandósoknak, akik nem tervezik, hogy szülésüknél jelen lesz választott orvos vagy szülésznő, kizárólag államilag finanszírozott várandósgondozást vesz igénybe, addig a választott szülészorvosnál és szülésznő részvételével szülni tervező anyák 89,5\%-a legalább részben magánellátást igényel.

\section{A várandósellátás és a demográfiai változók kapcsolata}

A várandósgondozási formák igénybevétele mindegyik elemzett demográfiai változóval - életkor, partnerkapcsolati helyzet és gyermekszám - szignifikáns összefüggést mutatott (2-4. táblázat).

Az életkor erősen összefüggött az igénybe vett ellátás formájával. Az államilag finanszírozott ellátás igénybevételének aránya a legfiatalabb két életkori csoport esetén volt az átlagosnál magasabb; a 20 évnél fiatalabbak $88,6 \%$-a, a $20-24$ évesek $63,7 \%$-a ezt veszi igénybe. A magánellátás esetén pedig a teljes minta értékéhez képest 30 év fölött figyelhettük meg az igénybevétel arányának emelkedését.

A partnerkapcsolati helyzet és az, hogy az anya hányadik gyermekét várta, közepes hatáserősséggel függött össze az anya által igénybe vett várandósellátás formájával. A partnerkapcsolati helyzet vonatkozásában a legmarkánsabb különbséget a teljes eloszláshoz képest a partnerrel nem együtt élók esetében találtuk: közülük

2. táblázat |A várandósgondozási formák igénybevételének megoszlása a várandósok életkora szerint

\begin{tabular}{lccc}
\hline A várandós életkora & & A 7. hónapig igénybe vett várandósgondozás típusa \\
\cline { 2 - 4 } & $\begin{array}{c}\text { Tb-támogatott } \\
\mathrm{n}(\%)\end{array}$ & $\begin{array}{c}\text { Vegyes } \\
\mathrm{n}(\%)\end{array}$ & $\begin{array}{c}\text { Magán } \\
\mathrm{n}(\%)\end{array}$ \\
\hline-19 & $442(88,6)$ & $33(6,6)$ & $24(4,8)$ \\
\hline $20-24$ & $777(63,7)$ & $261(21,4)$ & $181(14,8)$ \\
\hline $25-29$ & $847(38,2)$ & $687(31)$ & $681(30,7)$ \\
\hline $30-34$ & $706(28,4)$ & $845(34)$ & $934(37,6)$ \\
\hline $35-39$ & $402(27,6)$ & $489(33,6)$ & $566(38,8)$ \\
\hline $40-$ & $120(30,3)$ & $132(33,3)$ & $144(36,4)$ \\
\hline Összesen & $3294(39,8)$ & $2447(29,6)$ & $2530(30,6)$ \\
\hline
\end{tabular}

$\mathrm{n}=8271$

$\mathrm{Tb}=$ társadalombiztosítás

${ }^{*} \mathrm{p}<0,001$

${ }^{a} \mathrm{df}=10$, vagyis a Cramér-féle V 0,03 érték felett jelez gyenge, 0,10 érték felett közepes és 0,16 érték felett erős összefüggést

3. táblázat |A várandósgondozási formák igénybevételének megoszlása a várandósok partnerkapcsolati helyzete szerint

\begin{tabular}{lccc}
\hline $\begin{array}{l}\text { A várandós valós partnerkap- } \\
\text { csolati helyzete }\end{array}$ & A 7. hónapig igénybe vett várandósgondozás típusa \\
\cline { 2 - 4 } & $\begin{array}{c}\text { Tb-támogatott } \\
\mathrm{n}(\%)\end{array}$ & $\begin{array}{c}\text { Vegyes } \\
\mathrm{n}(\%)\end{array}$ & $\begin{array}{c}\text { Magán } \\
\mathrm{n}(\%)\end{array}$ \\
\hline Házastárssal él & $1246(27,6)$ & $1567(34,7)$ & $1703(37,7)$ \\
\hline Élettárssal él & $1801(52,7)$ & $824(24,1)$ & $790(23,1)$ \\
\hline Nem él partnerrel & $246(72,8)$ & $55(16,3)$ & $37(10,9)$ \\
\hline Összesen & $3293(39,8)$ & $2446(29,6)$ & $2530(30,6)$ \\
\hline
\end{tabular}

$\mathrm{n}=8269$

$\mathrm{Tb}=$ társadalombiztosítás

${ }^{*} \mathrm{p}<0,001$

${ }^{a} \mathrm{df}=4$, vagyis a Cramér-féle V 0,05 érték felett jelez gyenge, 0,15 érték felett közepes és 0,25 érték felett erős összefüggést 
4. táblázat |A várandósgondozási formák igénybevételének megoszlása a várandósok korábbi gyermekszáma szerint

\begin{tabular}{lccc}
\hline $\begin{array}{l}\text { A várandós hányadik } \\
\text { gyermekét várja? }\end{array}$ & \begin{tabular}{c} 
A $\begin{array}{c}\text { A támogatott } \\
\mathrm{n}(\%)\end{array}$ \\
\cline { 2 - 4 }
\end{tabular} & $\begin{array}{c}\text { Vegyes } \\
\mathrm{n}(\%)\end{array}$ & $\begin{array}{c}\text { Magán } \\
\mathrm{n}(\%)\end{array}$ \\
\hline Elsón & $1305(33,9)$ & $1288(33,5)$ & $1257(32,6)$ \\
\hline Második & $1019(37,5)$ & $779(28,6)$ & $922(33,9)$ \\
\hline Harmadik & $543(47,6)$ & $304(26,6)$ & $294(25,8)$ \\
\hline Legalább negyedik & $425(76,7)$ & $74(13,4)$ & $55(9,9)$ \\
\hline Összesen & $3292(39,8)$ & $2445(29,6)$ & $2528(30,6)$ \\
\hline
\end{tabular}

$\mathrm{n}=8265$

$\mathrm{Tb}=$ társadalombiztosítás

${ }^{*} \mathrm{p}<0,001$

${ }^{\mathrm{a}} \mathrm{df}=6$, vagyis a Cramér-féle V 0,04 érték felett jelez gyenge, 0,12 érték felett közepes és 0,2 érték felett erős összefüggést

72,8\% tb-támogatott ellátást vesz igénybe, magánellátást pedig csupán 10,9\%. A gyermekszámot illetően ez a tendencia a többedik gyermeket váróknál érvényesült: a gyermekszám emelkedésével az anya növekvő eséllyel vett igénybe kizárólag államilag finanszírozott ellátást, a magánellátás igénybevételének aránya pedig a legalább harmadik gyermek várása esetén maradt el a teljes minta arányától.

\section{A várandósellátás és a társadalmi-gazdasági státusz kapcsolata}

A várandósgondozási formák igénybevétele a vizsgálat céljára kialakított hierarchikus társadalmiháttér-változók mindegyikével szignifikáns összefüggést mutat (5-7. táblázat). Továbbá a Cramér-féle V-értékek alapján mindhárom esetben erôs összefüggésrôl beszélhetünk. A várandósok iskolai végzettségének emelkedésével fokozatosan tolódnak el a súlypontok a várandósgondozáson belül az állami szolgáltatásoktól a magángondozás felé. A különbség olyan jelentős, hogy a felsőfokú végzettségű anyáknak mindössze a 15,3\%-a jár kizárólag tb-támogatott várandósgondozásra, míg ugyanez az alapfokú végzettségú várandósok háromnegyedét $(75,6 \%)$ jellemzi a várandósság 7 . hónapjáig. A magán- és a tbtámogatott várandósgondozási formák kombinált igénybevétele kapcsán a közép- és a felsőfokú végzettségưek között kisebb a különbség. A magánellátás kizárólagossága azonban már döntően a legmagasabb végzettségi csoport jellemzője.

Az egy főre eső háztartási jövedelem szerint a lépcsőzetesség úgyszintén leképeződik. Míg a legalacsonyabb háztartás-jövedelmi csoportba tartozó várandósok 74\%-a kizárólag tb-támogatott várandósgondozást vesz igénybe, addig ennek aránya a jövedelmi szint emelkedésével fokozatosan csökken, akár 15-25 százalékpontos esést mutatva. A legmagasabb háztartás-jövedelmi ötödbe tartozó anyáknak már mindössze a 15,1\%-a veszi igénybe kizárólag a tb szolgáltatásait. Körükben azonban már 51,3\% azok aránya, akik kizárólag magán-várandósgondozásra járnak. Ugyanez a legalacsonyabb kvintilisben alig haladja meg a 10\%-ot. A hierarchikus tendencia - a háztartás-jövedelmi szint szerinti szelekció - egyértelmúen azonosítható a várandósgondozási formák igénybevételében.

5. táblázat |A várandósgondozási formák igénybevételének megoszlása a várandósok iskolai végzettsége szerint

\begin{tabular}{lccc}
\hline $\begin{array}{l}\text { A várandós legmagasabb iskolai } \\
\text { végzettsége }\end{array}$ & \begin{tabular}{c} 
A $\begin{array}{c}\text { A támogatott } \\
\mathrm{n}(\%)\end{array}$ \\
\cline { 2 - 4 }
\end{tabular} & $\begin{array}{c}\text { Vegyes } \\
\mathrm{n}(\%)\end{array}$ & $\begin{array}{c}\text { Magán } \\
\mathrm{n}(\%)\end{array}$ \\
\hline Alapfokú & $1976(75,6)$ & $378(14,5)$ & $261(10,0)$ \\
\hline Középfokú & $879(31,5)$ & $972(34,8)$ & $943(33,8)$ \\
\hline Felsőfokú & $438(15,3)$ & $1095(38,3)$ & $1325(46,4)$ \\
\hline Összesen & $3293(39,8)$ & $2445(29,6)$ & $2529(30,6)$ \\
\hline
\end{tabular}

$\mathrm{n}=8267$

$\mathrm{Tb}=$ társadalombiztosítás

${ }^{*} \mathrm{p}<0,001$

${ }^{a} \mathrm{df}=4$, vagyis a Cramér-féle V 0,05 érték felett jelez gyenge, 0,15 érték felett közepes és 0,25 érték felett erős összefüggést 
6. táblázat |A várandósgondozási formák igénybevételének megoszlása háztartás-jövedelmi ötödök szerint

\begin{tabular}{lccc}
\hline Háztartás-jövedelmi ötödök & A 7. hónapig igénybe vett várandósgondozás típusa \\
\cline { 2 - 4 } & $\begin{array}{c}\text { Tb-támogatott } \\
\mathrm{n}(\%)\end{array}$ & $\begin{array}{c}\text { Vegyes } \\
\mathrm{n}(\%)\end{array}$ & $\begin{array}{c}\text { Magán } \\
\mathrm{n}(\%)\end{array}$ \\
\hline 1. ötöd & $1095(74,2)$ & $220(14,9)$ & $161(10,9)$ \\
\hline 2. ötöd & $731(50,1)$ & $427(29,3)$ & $300(20,6)$ \\
\hline 3. ötöd & $495(35,1)$ & $468(33,2)$ & $446(31,7)$ \\
\hline 4. ötöd & $377(24,1)$ & $599(38,3)$ & $590(37,7)$ \\
\hline 5. ötöd & $222(15,1)$ & $495(33,6)$ & $755(51,3)$ \\
\hline Összesen & $2920(39,6)$ & $2209(29,9)$ & $2252(30,5)$ \\
\hline
\end{tabular}

$\mathrm{n}=7381$

$\mathrm{Tb}=$ társadalombiztosítás

${ }^{*} \mathrm{p}<0,001$

${ }^{a} \mathrm{df}=8$, vagyis a Cramér-féle V 0,03 érték felett jelez gyenge, 0,11 érték felett közepes és 0,18 érték felett erős összefüggést

7. táblázat |A várandósgondozási formák igénybevételének megoszlása a várandósok foglalkozási presztízse szerint

\begin{tabular}{|c|c|c|c|c|c|}
\hline \multirow{2}{*}{$\begin{array}{l}\text { A Treiman-féle foglalkozásipresz- } \\
\text { tízs-skála harmadai (SIOPS) }\end{array}$} & \multicolumn{5}{|c|}{ A 7. hónapig igénybe vett várandósgondozás típusa } \\
\hline & $\begin{array}{l}\text { Tb-támogatott } \\
\text { n (\%) }\end{array}$ & $\begin{array}{l}\text { Vegyes } \\
\mathrm{n}(\%)\end{array}$ & $\begin{array}{l}\text { Magán } \\
\text { n (\%) }\end{array}$ & Cramér-féle $\mathrm{V}^{\mathrm{a}}$ & Pearson-féle $\chi^{2}$ \\
\hline Alsó harmad & $1121(48,1)$ & $612(26,3)$ & $596(25,6)$ & 0,296 & $1335,422^{*}$ \\
\hline Középső harmad & $734(32,7)$ & $731(32,5)$ & $783(34,8)$ & & \\
\hline Felső harmad & $397(17,4)$ & $901(39,5)$ & $983(43,1)$ & & \\
\hline Még nem dolgozott & $667(87,6)$ & $59(7,8)$ & $35(4,6)$ & & \\
\hline Összesen & $2919(38,3)$ & $2303(30,2)$ & $2397(31,5)$ & & \\
\hline
\end{tabular}

$\mathrm{n}=7619$

SIOPS = standard nemzetközi foglalkozásipresztízs-skála; $\mathrm{Tb}$ = társadalombiztosítás

${ }^{*} \mathrm{p}<0,001$

${ }^{\mathrm{a}} \mathrm{df}=6$, vagyis a Cramér-féle V 0,04 érték felett jelez gyenge, 0,12 érték felett közepes és 0,2 érték felett erős összefüggést

A várandósok társadalmi hátterének harmadik komponenseként beemelt foglalkozásipresztízs-változó a fentebb azonosított összefüggéseket mutatja. A foglalkozási presztízs növekedésével a várandósgondozás határozottan a magánszféra szolgáltatói felé tolódik el. Az alacsonyabb foglalkozási presztízsû́ $s$ főleg a munkatapasztalattal egyáltalán nem rendelkező várandósok azok, akik jelentôsebb arányban fordulnak kizárólag a tb-támogatott várandósgondozás felé. Az utóbbiak körében ez szinte kizárólagos $(87,6 \%)$. A vegyes finanszírozású várandósgondozás esetében a foglalkozási presztízs szempontjából is kisebbek, de jól azonosíthatók a hierarchikus különbségek.

\section{A várandósellátás és az egészségi állapot kapcsolata}

A várandósok egészségi állapota viszonylag gyenge kapcsolatot mutatott a magán-, illetve a tb-támogatott várandósgondozás igénybevételével. A várandósságot megelőző időszakra vonatkozó szubjektív egészségmutató szerint (8. táblázat) azok az anyák, akik a saját egészségüket rossznak vagy nagyon rossznak tartották, lényegesen kisebb arányban választották a kizárólagosan közfinanszírozott ellátást, míg a vegyes rendszer igénybevétele az átlagosnál jóval gyakoribb volt, de ez az öszszefüggés nagyon gyengének bizonyult. Ugyanakkor a várandósság 7 . hónapjára vonatkozó szubjektív egészség (9. táblázat) éppen ellenkező hatást mutatott: a rossz/ nagyon rossz egészségúek nagy hányada $(73,1 \%)$ kizárólag állami várandósgondozást vett igénybe. Ha a kicsit objektívebb egészségmutatót vizsgáljuk, akkor azt láthatjuk, hogy a krónikus betegség hiánya növelte az állami ellátásokon való részvétel előfordulását, a betegség megléte inkább a magánorvosi ellátás felé terelte a gondozottakat (10. táblázat).

\section{A várandósellátás és a pszichés tünetek kapcsolata}

A különböző típusú várandósgondozási ellátást igénybe vevő nők három csoportja Kruskal-Wallis-teszttel vizsgálva a depresszív és a generalizált szorongásos tünetek gyakorisága és a várandóssággal összefüggő szorongások 
8. táblázat |A várandósgondozási formák igénybevételének megoszlása a várandósság előtti szubjektív egészségi állapot szerint

\begin{tabular}{|c|c|c|c|c|c|}
\hline \multirow{2}{*}{$\begin{array}{l}\text { A várandósság előtti szubjektív } \\
\text { egészségi állapot }\end{array}$} & \multicolumn{5}{|c|}{ A 7 . hónapig igénybe vett várandósgondozás típusa } \\
\hline & $\begin{array}{l}\text { Tb-támogatott } \\
\mathrm{n}(\%)\end{array}$ & $\begin{array}{l}\text { Vegyes } \\
\mathrm{n}(\%)\end{array}$ & $\begin{array}{l}\text { Magán } \\
\text { n }(\%)\end{array}$ & Cramér-féle Va & Pearson-féle $\chi^{2}$ \\
\hline Jó/nagyon jó & $2759(38,8)$ & $2102(29,6)$ & $2242(31,6)$ & 0,042 & $28,836^{*}$ \\
\hline Kielégítő & $424(44,7)$ & $289(30,5)$ & $235(24,8)$ & & \\
\hline Rossz/nagyon rossz & $438(15,3)$ & $1325(46,4)$ & $1095(38,3)$ & & \\
\hline Összesen & $3287(39,8)$ & $2446(29,6)$ & $2528(30,6)$ & & \\
\hline
\end{tabular}

$\mathrm{n}=8261$

$\mathrm{Tb}=$ társadalombiztosítás

${ }^{*} \mathrm{p}<0,001$

${ }^{\mathrm{a}} \mathrm{df}=4$, vagyis a Cramér-féle V 0,05 érték felett jelez gyenge, 0,15 érték felett közepes és 0,25 érték felett erős összefüggést

9. táblázat |A várandósgondozási formák igénybevételének megoszlása a várandósság alatti szubjektív egészségi állapot szerint

\begin{tabular}{|c|c|c|c|c|c|}
\hline \multirow{2}{*}{$\begin{array}{l}\text { A várandósság alatti szubjektív } \\
\text { egészségi állapot }\end{array}$} & \multicolumn{5}{|c|}{ A 7 . hónapig igénybe vett várandósgondozás típusa } \\
\hline & $\begin{array}{c}\text { Tb-támogatott } \\
\mathrm{n}(\%)\end{array}$ & $\begin{array}{l}\text { Vegyes } \\
\mathrm{n}(\%)\end{array}$ & $\begin{array}{l}\text { Magán } \\
\text { n (\%) }\end{array}$ & Cramér-féle $\mathrm{V}^{\mathrm{a}}$ & Pearson-féle $\chi^{2}$ \\
\hline Jó/nagyon jó & $2584(37,1)$ & $2125(30,5)$ & $2260(32,4)$ & 0,100 & $163,610^{*}$ \\
\hline Kielégítő & $618(52,6)$ & $299(25,5)$ & $257(21,9)$ & & \\
\hline Rossz/nagyon rossz & $87(73,1)$ & $21(17,6)$ & $11(9,2)$ & & \\
\hline Összesen & $3289(39,8)$ & $2445(29,6)$ & $2528(30,6)$ & & \\
\hline
\end{tabular}

$\mathrm{n}=8262$

$\mathrm{Tb}=$ társadalombiztosítás

${ }^{*} \mathrm{p}<0,001$

${ }^{a} \mathrm{df}=4$, vagyis a Cramér-féle V 0,05 érték felett jelez gyenge, 0,15 érték felett közepes és 0,25 érték felett erős összefüggést

10. táblázat |A várandósgondozási formák igénybevételének megoszlása krónikus betegség megléte szerint

\begin{tabular}{lcccc}
\hline Krónikus betegség & \multicolumn{2}{c}{ A 7. hónapig igénybe vett várandósgondozás típusa } \\
\cline { 2 - 4 } & $\begin{array}{c}\text { Tb-támogatott } \\
\mathrm{n}(\%)\end{array}$ & $\begin{array}{c}\text { Vegyes } \\
\mathrm{n}(\%)\end{array}$ & $\begin{array}{c}\text { Magán } \\
\mathrm{n}(\%)\end{array}$ & $\begin{array}{c}\text { Cramér-féle V } \\
\text { Parson-féle } \chi^{2}\end{array}$ \\
\hline Van betegség & $577(32,4)$ & $576(32,3)$ & $628(35,3)$ & 0,081 \\
\hline Nincs betegség & $2706(41,9)$ & $1862(28,8)$ & $1895(29,3)$ \\
\hline Összesen & $3283(39,8)$ & $2438(29,6)$ & $2523(30,6)$ \\
\hline
\end{tabular}

$\mathrm{n}=8244$

$\mathrm{Tb}$ = társadalombiztosítás

${ }^{*} \mathrm{p}<0,001$

${ }^{\mathrm{a}} \mathrm{df}=2$, vagyis a Cramér-féle V 0,07 érték felett jelez gyenge, 0,21 érték felett közepes és 0,35 érték felett erős összefüggést

és félelmek összesített mértéke mentén egyaránt különbözött, ugyanakkor a próbák hatásméretei gyenge összefüggésekre engednek következtetni (11. táblázat). Mann-Whitney-próbákkal páronként tovább vizsgálva, mindhárom pszichológiai skála esetén igazolódott, hogy a pszichés problémák mértéke a tb-támogatott rendelésre járók körében volt a legmagasabb, és a magánrendelésre járók körében a legalacsonyabb ( $\mathrm{p}<0,009$ minden esetben).
11. táblázat |A pszichés tünetek különbségei a három csoportban

\begin{tabular}{lccc}
\hline Változó & $\chi^{2}(2)$ & $\mathrm{n}$ & $\eta^{2}$ \\
\hline A depresszív tünetek gyakorisága & $189,969 *$ & 8391 & 0,022 \\
$\begin{array}{l}\text { A generalizált szorongásos tünetek } \\
\text { gyakorisága }\end{array}$ & $104,563^{*}$ & 8297 & 0,012 \\
$\begin{array}{l}\text { A várandóssággal összefüggó } \\
\text { szorongás mértéke }\end{array}$ & $107,967^{*}$ & 8389 & 0,013 \\
\hline
\end{tabular}

${ }^{*} \mathrm{p}<0,001$ 
A Várandóssággal Összefüggő Gondolatok Kérdőív tételeinek együttjárásait az ellátás módjával egyenként, kereszttáblákkal is megvizsgálva azt találtuk, hogy az ellátás módja a legjelentősebb kapcsolatot az „Aggódom, hogy nehéz vagy komplikált vajúdásom és szülésem lesz" tétellel mutatta, amellyel közepes mértékben függött össze. Ezzel kapcsolatban a tb-támogatott rendelésre járók 20,2\%-ának, a vegyes ellátást igénybe vevôk 10,3\%ának és a magánellátást igénybe vevők 8,7\%-ának voltak nagymértékú aggodalmai, amely értékekkel ez a félelem minden csoportban a leggyakoribbak közé tartozik. A skála többi kérdésével a várandósellátás formája gyenge kapcsolatban állt, azonban mindegyik esetben igaznak bizonyult, hogy a magánellátást igénybe vevők alacsonyabb mértékû aggodalmakról számolnak be, mint a kizárólag tb-támogatott ellátást igénybe vevők.

\section{Megbeszélés}

A várandósgondozási rendszer szolgáltatásainak igénybevételét 2018-ban gyermeküket váró magyarországi várandós anyák országos reprezentatív mintáján vizsgáltuk. A hazai szisztéma finanszírozási sajátosságaihoz illeszkedve az elemzés során magán-, tb-támogatott és vegyes típusú várandósgondozásban részt vevő anyákat különítettünk el.

Kiinduló feltételezésünket, mely szerint a hazai várandósellátás különböző finanszírozású formáinak igénybevételét az anyák szocioökonómiai, demográfiai, pszichés és egészségi jellemzői komplex módon befolyásolják, a kapott eredmények részlegesen támasztják alá.

A társadalmi-gazdasági háttér és a várandósgondozási ellátás szoros kapcsolata egyértelműen azonosítható. A várandósellátás formájával az anya és a család szocioökonómiai jellemzői mutatják a legerősebb kapcsolatot. Az e szempontból feltárt, várandósok közti különbségek hierarchikus módon képeződnek le az állami/vegyes/ magán ellátás tengelyén. Vizsgálatunk eredményeként - Chiavarini és mtsai [14], Rowe és mtsai [15], Borrell és mtsai [16], Moran és mtsai [17], valamint Braveman és $m$ tsai [10] külföldi adatokon alapuló megállapításaival összhangban - a magán- és az állami ellátórendszerek kiegészítő egymásmellettiségével jellemezhető magyarországi rendszerben is kimutathatók a magánellátáshoz kapcsolható fokozottabb társadalmi egyenlőtlenségek. A várandósgondozási magánellátás Magyarországon a választott szülészorvos-szülésznő igénybevételével is erős összefüggést mutat - a társadalmi egyenlőtlenségeket átcsatornázva ezzel a szülésig.

A fogadott orvos felkérését többek között a nők azon igénye motiválhatja, hogy a várandósgondozás folyamatában biztonságban érezzék magukat, megfelelő ellátásban és azon szakember gondozásában részesüljenek, aki a későbbiekben a szülésüknél is közremúködik majd [25]. Azon eredményünk, miszerint egyes pszichés problémák és a várandóssággal és szüléssel összefüggő szoron- gás mértéke valamelyest alacsonyabb előfordulást mutat a magánellátást igénybe vevők körében, részben ennek tükrében értelmezhető. Feltételezhetjük, hogy a választott szülészorvos magánrendelésén való részvétel növeli a kapott ellátás minőségének szubjektív értékelését, és annak ígéretét hordozza magában, hogy a megismert orvos jelenik meg a szülésnél. A magánellátásban való részvétel ezáltal hozzájárulhat a várandós nő mentális jóllétéhez és alacsonyabb szorongásszintjéhez, oksági összefüggés kimutatására mindazonáltal a jelen elrendezés nem alkalmas. Mindemellett a várandósgondozási forma pszichológiai változókkal mutatott összefüggéseit a szocioökonómiai különbségek is magyarázhatják [19], ezért a státuszhatás szerepét többváltozós módszertannal is vizsgálni szükséges.

Az egészségi állapotból fakadó kockázati tényezők - jóllehet krónikus betegség esetén kapcsolatuk azonosítható - Moran és mtsai [17] írországi tapasztalataival egybevágóan nem befolyásolják számottevően a várandósgondozási rendszer igénybevételét; valószínúleg a szocioökonómiai státusz hatása érvényesül mind az egészségi állapot, mind pedig az ellátórendszer igénybevételének vonatkozásában.

Jelen elemzésünk nem irányul a teljes magyarországi várandósgondozási rendszer komplex leírására, annak csupán egy kis részletét, a magán- és az állami finanszírozású ellátások igénybevétele mögött húzódó eltérő társadalmi-gazdasági háttér bemutatását tüztük ki tanulmányunk céljául. A Kohorsz '18 longitudinális kutatás egymást követő hullámainak adatbázisai a jövőben majd lehetővé teszik a mélyebb elemzéseket is.

A probléma vizsgálatának további kutatási terveiben a hazai finanszírozási rendszernek a várandósgondozás megítélésére, valamint a szülés lefolyására és annak szubjektív értékelésére gyakorolt hatásainak vizsgálata szerepel. Ezáltal válik majd értékelhetôvé, hogy a különböző finanszírozási formák és az azokhoz kapcsolódó háttéregyenlőtlenségek vezetnek-e az anyára és születendő gyermekére nézve hátrányos szülési kimenethez vagy élményekhez.

Anyagi támogatás: A Kohorsz '18 kutatás adatfelvétele az EFOP-1.9.4-VEKOP-16-2016-00001. azonosítószámú, „A szociális ágazat módszertani és információs rendszereinek megújítása" címú európai uniós projekt keretében valósult meg.

Szerzői munkamegosztás: A cikk valamennyi részének megírásában (bevezetés, módszer, eredmények, megvitatás) és a statisztikai elemzések elkészítésében B. J., K. K. és V. Zs. egyaránt részt vett. A cikk végleges változatát valamennyi szerző elolvasta és jóváhagyta.

Érdekeltségek: A szerzőknek nincsenek érdekeltségeik. 


\section{Köszönetnyilvánítás}

A szerzők köszönetüket fejezik ki mindazon várandósoknak és védőnőiknek, akik a kérdoóiv megválaszolásával és felvételével lehetővé tették a Kohorsz '18 kutatás megvalósulását.

\section{Irodalom}

[1] Decree No. 26/2014. (IV. 8.) of the Ministry of Human Capacities about Pregnancy Care in Hungary. (26/2014. (IV. 8.) EMMI rendelet a várandósgondozásról.) Available from: https://net.jogtar.hu/jogszabaly?docid=al400026.emm [accessed: March 7, 2021]. [Hungarian]

[2] Fawsitt CG, Bourke J, Lutomski JE, et al. What women want: Exploring pregnant women's preferences for alternative models of maternity care. Health Policy 2017; 121: 66-74.

[3] Hollowell J, Li Y, Malouf R, et al. Women's birth place preferences in the United Kingdom: a systematic review and narrative synthesis of the quantitative literature. BMC Pregnancy Childbirth 2016; 16: 213.

[4] Larkin P, Begley CM, Devane D. Women's preferences for childbirth experiences in the Republic of Ireland; a mixed methods study. BMC Pregnancy Childbirth 2017; 17: 19.

[5] Sági C, Baji P. Gratitude money in obstetrics - results of a qualitative study. [Hálapénz a szülészetben - egy kvalitatív vizsgálat eredményei.] Biztosítás és Kockázat 2017; 4: 82-97. [Hungarian]

[6] Roberts CL, Tracy S, Peat B. Rates for obstetric intervention among private and public patients in Australia: population based descriptive study. BMJ 2000; 321: 137-141.

[7] World Health Organization Commission on Social Determinants of Health. Closing the gap in a generation: health equity through action on the social determinants of health. World Health Organisation, Geneva, 2008.

[8] WHO recommendations on antenatal care for a positive pregnancy experience. World Health Organisation, Geneva, 2016.

[9] McRae DN, Muhajarine N, Stoll K, et al. Is model of care associated with infant birth outcomes among vulnerable women? A scoping review of midwifery-led versus physician-led care. SSM-Popul Health 2016; 2: 182-193. [Erratum: SSM Popul Health 2017; 3: 817.]

[10] Braveman P, Marchi K, Egerter S, et al. Poverty, near-poverty and hardship around the time of pregnancy. Matern Child Health J. 2010; 14: 20-35.

[11] Sutherland G, Yelland J, Brown S. Social Inequalities in the Organization of Pregnancy Care in a Universally Funded Public Health Care System. Matern Child Health J. 2012; 16: 288296.

[12] Kramer MS, Séguin L, Lydon J, et al. Socio-economic disparities in pregnancy outcome: why do the poor fare so poorly? Paediatr Perinat Epidemiol. 2000; 14: 194-210.

[13] Joseph KS, Liston RM, Dodds L, et al. Socioeconomic status and perinatal outcomes in a setting with universal access to essential health care services. CMAJ 2007; 177: 583-590.

[14] Chiavarini M, Lanari D, Minelli L, et al. Socio-demographic determinants and access to prenatal care in Italy. BMC Health Serv Res. 2014; 14: 174

[15] Rowe RE, Magee H, Quigley MA, et al. Social and ethnic differences in attendance for antenatal care in England. Public Health 2008; 122: 1363-1372.

[16] Borrell C, Fernandez E, Schiaffino A, et al. Social class inequalities in the use of and access to health services in Catalonia, Spain: what is the influence of supplemental private health insurance? Int J Qual Health Care 2001; 13: 117-125.
[17] Moran PS, Daly D, Wuytack F, et al. Predictors of choice of pub lic and private maternity care among nulliparous women in Ire land, and implications for maternity care and birth experience. Health Policy 2020; 124: 556-562.

[18] Baji P, Rubashkin N, Szebik I, et al. Informal cash payments for birth in Hungary: are women paying to secure a known provider, respect, or quality of care? Soc Sci Med. 2017; 189: 86-95.

[19] Lancaster CA, Gold KJ, Flynn HA, et al. Risk factors for depressive symptoms during pregnancy: a systematic review. Am J Obstet Gynecol. 2010; 202: 5-14.

[20] Kapitány B. The target population and the sampling. In: Veroszta Zs. (ed.) Technical report. Growing Up in Hungary - Cohort '18 Hungarian birth cohort study. Prenatal research, preparational phase. Working Papers on Population, Family and Welfare, No. 30. Hungarian Demographic Research Institute, Budapest, 2018; pp. 7-12.

[21] Szabó L, Boros J, Fábián I, et al. Prenatal study wave. Technical report. Growing Up in Hungary - Cohort '18 Hungarian birth cohort study. Research Reports 102. [Kohorsz '18 Magyar Születési Kohorszvizsgálat. Várandós kutatási szakasz. Technikai riport. Kutatási Jelentések 102.] Budapest, Központi Statisztikai Hivatal, Népességtudományi Kutatóintézet, 2020. [Hungarian]

[22] Veroszta Zs. (ed.) Technical report. Growing Up in Hungary Cohort '18 Hungarian birth cohort study. Prenatal research, preparational phase. Working Papers on Population, Family and Welfare, No. 30. Hungarian Demographic Research Institute, Budapest, 2018.

[23] Duncan OD. A Socioeconomic index for all occupations. In: Reiss AJ Jr. (ed.) Occupations and social status. Free Press of Glencoe, New York, NY, 1961; pp. 109-138.

[24] Central Statistical Office. Standard Classification of Occupations. [Központi Statisztikai Hivatal. Foglalkozások Egységes Osztályozási Rendszere (FEOR-08)]. Available from: https://www. ksh.hu/docs/szolgaltatasok/hun/feor08/feorlista.html [accessed: March 7, 2021]. [Hungarian]

[25] International Labour Organization. International Standard Classification of Occupations. ISCO-08 Structure, index correspondence with ISCO-88. Available from: https://www.ilo.org/public/english/bureau/stat/isco/isco08/ [accessed: March 7, $2021]$.

[26] Central Statistical Office. Correlation between four digit systematic registry of FEOR-93 and FEOR-08. [Központi Statisztikai Hivatal. Megfeleltetés a FEOR-93 és a FEOR-08 négyszámjegyes rendszeres jegyzéke között.] Available from: https://www. ksh.hu/docs/osztalyozasok/feor/fordkulcs_feor93_feor08_ hu.pdf [accessed: March 7, 2021]. [Hungarian]

[27] Treiman, DJ. Occupational prestige in comparative perspective. Academic Press, New York, NY, 1977.

[28] Ganzeboom HB, Treiman DJ, Ultee WC. Comparative intergenerational stratification research: three generations and beyond. Annu Rev Sociol. 1991; 17: 277-302.

[29] Ganzeboom HB, Treiman DJ. Internationally comparable measures of occupational status for the 1988 International Standard Classification of Occupations. Social Sci Res. 1996; 25: 201239.

[30] Radloff LS. The CES-D Scale: a self-report depression scale for research in the general population. Appl Psychol Measure. 1977; 1: 385-401.

[31] Bracke P, Levecque K, Van de Velde S. The psychometric properties of the CES-D 8 depression inventory and the estimation of cross-national differences in the true prevalence of depression. Ghent University, Ghent, 2008.

[32] Szeifert L. Depression and quality of life in patients with chronic kidney disease. Doctoral dissertation. [Depresszió és életminőség krónikus veseelégtelenségben szenvedő betegek körében. Doktori értekezés.] Semmelweis Egyetem Mentális Egészségtudományok Doktori Iskola, Budapest, 2010. [Hungarian] 
[33] Kroenke K, Spitzer RL, Williams JBW, et al. Anxiety disorders in primary care: prevalence, impairment, comorbidity, and detection. Ann Intern Med. 2007; 146: 317-325.

[34] Rini CK, Dunkel-Schetter C, Wadhwa PD, et al. Psychological adaptation and birth outcomes: the role of personal resources, stress, and sociocultural context in pregnancy. Health Psychol. 1999; 18: 333-345.

[35] Kopcsó K, Bornemisza Á, Sz Makó H. The Hungarian adaptation of the Pregnancy Related Thoughts scale measuring preg- nancy related anxiety. [A várandóssággal kapcsolatos szorongást mérő Pregnancy Related Thoughts kérdőív hazai adaptálása.] Orv Hetil. 2018; 159: 1754-1760. [Hungarian]

(Boros Julianna, Budapest, Buday L. u. 1-3., 1024 e-mail: boros@demografia.hu)

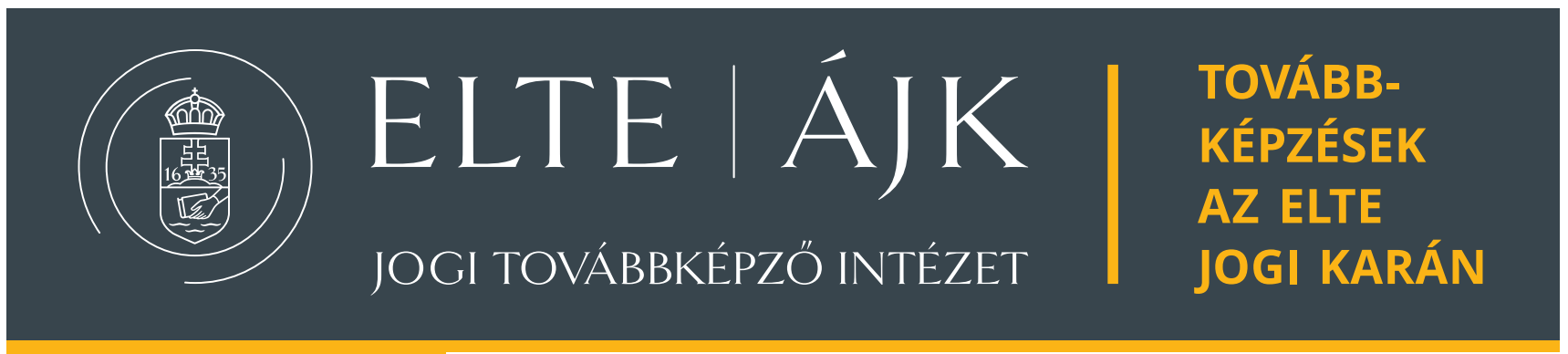

Helyszín:

ELTE Főépület,

1053 Budapest,

Egyetem tér 1-3.

További információk:

https://jotoki.elte.hu/

Jelentkezési határidő:

2021. augusztus 31 .

\section{Egészségügyi szakjogász képzés}

- átfogó elméleti és gyakorlati jogi tudást biztosít az egészségügy területén

- hatékony segítség az egészségügyi intézménymúködtetés átlátásában, az egészségpolitikai döntéshozatal, az állami és a magán-egészségbiztosítás, egészségügyi ellátás jogalkotás komplex működési folyamatainak megértésében

- akiknek ajánljuk: egészségügyi joggal foglalkozó bírók, hatósági tisztviselők, ügyvédek, egészségügyi intézményi jogtanácsosok, gyógyszerforgalmazó cégek, egészségügyi beszállítók

\section{Jogi szakokleveles orvos- és egészségügyi szakember képzés}

• hatékony jogi, igazgatási problémakezelés az egészségügy működése és működtetése során - a képzés fontos feladata, hogy kialakítsa a betegellátással kapcsolatos konfliktushelyzetek felismerésének és megfelelő kezelésének, a betegjogok gyakorlati érvényre juttatásának képességét

- akiknek ajánljuk: orvosok, fogorvosok, gyógyszerészek

Toválb bi képzéseink az egészségügyben dolgozók számára:

• Adatbiztonsági és adatvédelmi szakjogász • Munkajogi szakjogász • Adójogi szakjogász

A cikk a Creative Commons Attribution 4.0 International License (https://creativecommons.org/licenses/by/4.0/) feltételei szerint publikált Open Access közlemény, melynek szellemében a cikk bármilyen médiumban szabadon felhasználható, megosztható és újraközölhető, feltéve, hogy az eredeti szerző és a közlés helye, illetve a CC License linkje és az esetlegesen végrehajtott módosítások feltüntetésre kerülnek. (SID_1) 